\title{
A theological response to collective trauma in South Africa
}

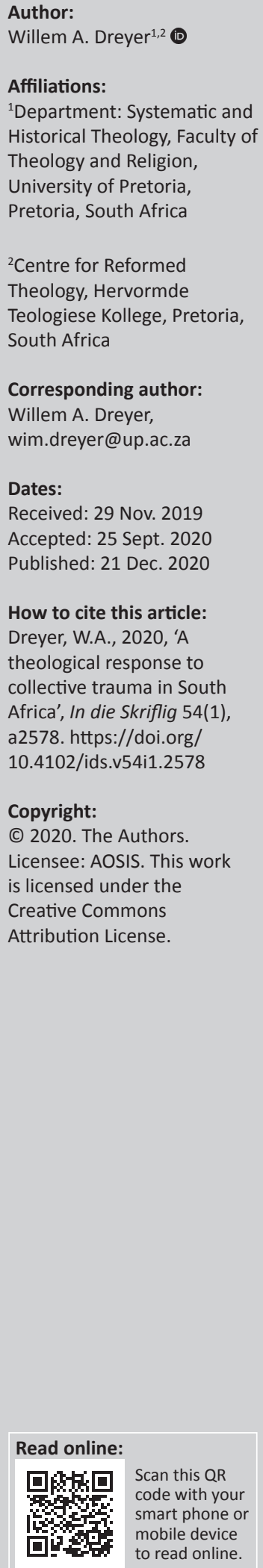

This contribution in the field of public theology explores two questions: (1) Could South Africa be regarded as a traumatised society, presenting with acute symptoms of post-traumatic disorder and (2) what would be an appropriate theological response to a traumatised society? These questions became even more acute with the outbreak of the Covid-19 pandemic during 2020. Historical events and current statistical data relevant to the first question are presented, which could indicate that South Africa might indeed be regarded as a highly traumatised society. The second question is discussed from the perspective of reformed theology. This limits the research focus, based on the assumption that all theology and all churches respond in a particular way to traumatic events and the effects of individual and collective trauma.

Keywords: Apartheid; Barth; Calvin; Christian Institute; Collective trauma; Colonialism; Cottesloe Conference; Crime statistics in South Africa; Public Theology; Reformed Theology.

\section{Introduction}

In recent years, public theology has become increasingly popular, with great diversity in content and methodology. Mannion (2009:122) is of the opinion that 'the best public theology involves theological hermeneutics in the service of moral, social and political praxis'. To this definition of public theology, one could also add 'assisting the church to live with integrity within society' (see Dreyer 2018:1-2). Public theology is practised at the interface between religion and society, and between church and community.

This contribution falls within the ambit of public theology. It will explore two questions: Could South Africa be regarded as a traumatised society, presenting with acute symptoms of collective trauma and if so, what would be an appropriate theological response to a traumatised society?

But what is trauma? According to The Center for Treatment of Anxiety and Mood Disorders (n.d.), trauma could be defined as follows:

\footnotetext{
In general, trauma can be defined as a psychological, emotional response to an event or an experience that is deeply distressing or disturbing ... Complex trauma happens repetitively. It often results in direct harm to the individual. The effects of complex trauma are cumulative. The traumatic experience frequently transpires within a particular time frame or within a specific relationship, and often in a specific setting. Post-Traumatic Stress Disorder (PTSD) can develop after a person has been exposed to a terrifying event or has been through an ordeal in which intense physical harm occurred or was threatened ... Over time, these emotional responses may fade, but a survivor may also experience reactions long-term (including) anger, persistent feelings of sadness and despair, unpredictable emotions, intense feelings of guilt, an altered sense of shame as well as feelings of isolation and hopelessness. (n.p.)
}

It is not only individuals who might experience trauma as well as post-traumatic stress disorder (PTSD). Much research had been done on 'collective' or 'cultural' trauma. There are many examples of how traumatic events and atrocities 'framed ... collective identities inside the narrative of progress' (Alexander 2012:142). Collective trauma could be defined as layers of traumatic events which a community experiences over an extended period of time, which manifests in various ways, including violent behaviour. This is exacerbated by the meaning a specific community attached to certain events, to such an extent that the interpretation or meaning or experience of the traumatic event is not dependent or in correlation with the original events. As a result, traumatic events could enter the realm of mythology and the sacral. A narrative is created that perpetuates the trauma and reacts violently to any alternative narrative, which denies the original trauma. It becomes imbedded in the collective memory and psyche. It could fade over time, but returns with a vengeance, often triggered by a next traumatic experience. 


\section{South Africa: A traumatised society?}

South Africa is a Tale of Two Cities, reflecting the best and the worst of times. On the one hand, South Africa is an extremely beautiful country with generous and warm-hearted people; at the same time, South Africa is an extremely traumatised society. Brutal conflict has been part of South African society up to this day, as was seen in the outbreak of xenophobic attacks during September 2019. Layers of conflict and trauma manifest themselves in typical PTSD behaviour, such as anxiety, fear, violence and bizarre acts of criminality.

South Africans had more than their share of war, xenophobia and racism during the 19th and 20th centuries. Between 1779 and 1879, nine Cape Frontier Wars between the Xhosa people and European settlers took place. It is also known as 'Africa's 100 Years War'. It is only one example of the brutal effects of colonialisation. Another is the Anglo-Boer War (1899-1902), during which the British Army established concentration camps for women and children all over South Africa. Approximately 27000 women, children and elderly men died in these concentration camps, approximately $20 \%$ of the Boer republics' white population. During that same period, the British Army kept 38000 Black and Coloured farm workers in separate concentration camps. The mortality in these camps was extremely high. This had left a scar which still surfaces from time to time.

After the Anglo-Boer War traumatic events followed in quick succession:

- The Rebellion (1914).

- First World War (1914-1918).

- The Spanish Flu Epidemic, which orphaned thousands of children (1918).

- The Great Depression and Drought (1933).

- $\quad$ The Second World War (1939-1945).

Within the borders of South Africa, violence, racism and conflict escalated dramatically after the Sharpeville massacre (21 March 1960) when police killed 69 black people and injured 180 more when they were protesting outside the police station at Sharpeville. Violent protests continued well after the first democratic election of 1994 and still is a feature of South African society (Dreyer 2016:4).

The South African Border War, also known as the Namibian War of Independence, was a conflict that occurred in Namibia, Zambia and Angola from 26 August 1966 to 21 March 1990. During this time, military service became compulsory for all white male South African citizens. Many of them were exposed to extreme traumatic experiences. The South African Border War had an immense social, cultural and political impact on South African society. It resulted in loss of life (1804 South African soldiers) and much trauma, not only for the soldiers in active service but also for families back home who lost sons and fathers. Furthermore, one should also take into consideration related incidents of suicide and alcoholism, as well as the effect it had on the general population and many civilian casualties.

From 1960 up to 1994, civil war was a real possibility in South Africa (see Dreyer 2016). From 1960 onwards, attacks on civil, police and military targets escalated. A state of emergency was declared. Hundreds of activists were arrested. Trials resulted in harsh prison sentences, even executions. Over a period of 28 years (1961-1989), 134 political activists were executed by hanging (see Dreyer 2016). In the decade after the Soweto uprising (1976-1986) alone, 130 people were 'executed' by the liberation movements. Many executions were not recorded as such. Of these 'executions', 30 were members of security forces and 100 were civilians, 40 were white and 60 black. On both sides of the conflict, gross human rights violations took place.

Chapter 4 of the Report of the South Africa (SA) Truth and Reconciliation Commission (of which Archbishop Desmond Tutu was the chairman) also found that liberation movements such as the African National Congress (ANC) and Pan Africanist Congress (PAC) 'committed gross violations of human rights in the course of their political activities and armed struggles, acts for which they are morally and politically accountable' (Nelson Mandela Centre of Memory n.d.):

Political violence in the province of KwaZulu-Natal (KZN), South Africa, has, according to some sources, taken as many as 20000 lives since 1984, especially since September 1987, when open warfare broke out in the Pietermaritzburg region with a series of territorial battles between Inkatha and the (ANC aligned) United Democratic Front. (see report of the Centre for the Study of Violence and Reconciliation (CSVR) compiled by Rupert Taylor [2002:3])

At present, one of the major topics of discussion in South Africa is the attacks on farmers and their families. The following statistics show the incidence of attacks on white farmers in rural areas (Afriforum Research Institute 2019:3).

Many farmers believe there are political motives behind these attacks. Many of these attacks were unusually cruel, including torture and rape. However, the South African government and several research bodies are convinced that the motives for these attacks are not political in nature but rather economical. Farms are isolated and had become an easy target for criminals.

The attacks on farms should be understood within the context of exceptionally high incidence of crime and more specifically, murder (see Table 1). An average of 20000 people are murdered in South Africa annually, mostly in domestic violence. The incidence of femicide and child murder increased during the Covid-19 lockdown period of 2020. It could be argued that the high incidence of crime could be the result of prolonged trauma leading to feelings of anger, hopelessness and frustration. According to South African Police (n.d.), the statistics for 2017-2018 period is presented in Table 2. 
The trauma experienced by farmers in South Africa is expounded by the question of land expropriation; simultaneously many black South Africans are extremely traumatised by the fact that after 25 years of democracy, they still live in abject poverty in squatter camps and very little access to resources like land, capital and education. The Economic Freedom Fighters (EFFs), founded by Julius Malema, insists that the redistribution of the land by means of expropriation without compensation must be enforced by government. The National Assembly decided to review Section 25 of the Constitution of the Republic of South Africa in order to cater for the principle of land expropriation without compensation.

It is ironic that one of the most outspoken critics of land expropriation is the Zulu king. The largest land owner in South Africa is the Ingonyama Trust, a corporate entity which administers land which belongs to the Zulu people in terms of traditional law, as represented by the Zulu king. The Trust owns $29.67 \%$ of the land in $\mathrm{KZN}$, which is equivalent to 28000 square kilometres. The South African Government owns $24 \%$ of South African land and black people, in traditional areas, own 34\%. Only 33\% of land in South Africa is owned directly by private individuals. These statistics are often disputed and without exception lead to heated debate and an increased feeling of alienation, insecurity and trauma.

TABLE 1: Black-on-black violence resulted in significant loss of life.

\begin{tabular}{lcc}
\hline Period & No. of murders & No. of reported attacks \\
\hline $1996-1997$ & 84 & 433 \\
$1997-1998$ & 142 & 490 \\
$1998-1999$ & 144 & 827 \\
$1999-2000$ & 144 & 823 \\
$2000-2001$ & 147 & 908 \\
$2001-2002$ & 140 & 1069 \\
$2002-2003$ & 103 & 903 \\
$2003-2004$ & 88 & 773 \\
$2004-2005$ & 82 & 694 \\
$2005-2006$ & 88 & 636 \\
$2006-2007$ & 86 & 794 \\
$2010-2011$ & 80 & 532 \\
$2011-2012$ & 56 & 523 \\
$2012-2013$ & 59 & 566 \\
$2013-2014$ & 57 & 517 \\
$2014-2015$ & 60 & 490 \\
$2015-2016$ & 49 & 446 \\
$2016-2017$ & 74 & 357 \\
\hline
\end{tabular}

Source: Claasen, L., 2017, Plaasaanvalle en plaasmoorde in Suid-Afrika, Afriforum Navorsingsinstituut, Centurion.

TABLE 2: The statistics of murder victims in South Africa by age and sex for 2017-2018.

\begin{tabular}{lc}
\hline & Murder victims in South Africa by age and sex (2017-2018) \\
\hline Victims & No. of murders \\
\hline Men & 16421 \\
Women & 2930 \\
Girls & 294 \\
Boys & 691 \\
\hline Total & $\mathbf{2 0 3 3 6}$ \\
\hline
\end{tabular}

Source: Statistics South Africa, 2020, Governance, Public Safety and Justice Survey, Statistical Release P0341, Department of Statistics South Africa, Pretoria, viewed 01 February 2020, from http://www.statssa.gov.za/?pageid=1854\&PPN=P0341\&SCH=7678.

SA, South Africa.
The trauma South Africans experience is also evident in emigration figures as well as the general demographic. At present, 183000 South Africans live in Australia. The emigration to New Zealand has reached an annual mark of 10 000. Emigration has become the third largest driver in real estate and the selling of property. The major reasons for emigration are security and safety concerns, lack of clear economic policies, widespread corruption and a weakening education system. The underlying driving force behind emigration is the experience of personal and collective trauma. These factors had such an impact on younger families that many of them are looking for greener pastures elsewhere. According to Business Tech (2019), more than 25000 highly skilled people (mostly who had their education in private schools), leave South Africa annually, of which the majority are black. It seems as if trauma has no racial bias.

Another indicator of negative perceptions is demographics. Amongst white South Africans, the birth rate has dropped with $75 \%$ over the past 30 years. All in all, the white population declined with $20 \%$ to less than 4 million. This had a major impact on churches in South Africa.

These examples are sufficient to confirm the premise that South Africa should be regarded as a traumatised society. Since 1994, when Nelson Mandela and Archbishop Desmond Tutu led South Africa to be the rainbow nation of the world, 500000 people died a violent death, more than many countries where there is armed conflict. It seems as if the transition to a democratic South Africa after 1994 did not alleviate the trauma which ordinary South Africans from every ethnic, cultural or age group had suffered over an extended period of time. It could even be argued that trauma had become part and parcel of the collective psyche of the South African people, which becomes evident in high levels of anxiety, fear and violence.

\section{Examples of theological responses to trauma Introductory remarks}

Trauma is not unique to South Africa. Many countries are struggling with a traumatic past. It is also not unique to the 21st century. Trauma is part of humanity since earliest times. The question is: How do we respond theologically to individual and collective trauma? How is it possible to be church in a traumatised society? How would the response of churches in disadvantaged communities differ from churches in more affluent communities?

In this section, some historical examples of theological responses to traumatic events and sociopolitical change are discussed. The examples are mainly from the Reformed tradition, without suggesting that other churches and traditions are not important. It is simply about limiting the scope of the research. The selection of theologians is more or less arbitrary, except for the fact that they are historically and theologically associated with the broader Reformed tradition, 
as well as the fact that they all engaged in the sociopolitical issues of their time in a very direct manner. Social awareness and the ability to reflect theologically on social issues are some of the remarkable qualities of Reformed theology. However, it is a question to what extent this general observation still holds true.

\section{Luther}

During the 16th century, common people, politicians, businessmen and theologians had to deal with significant sociopolitical and intellectual change. For instance, from the 15 th to 18th centuries, famine became more frequent because of the Little Ice Age. The colder climate (average $2^{\circ}$ colder around 1600) resulted in frequent harvest failures. The great famine of the 1590s continued deep into the 17th century. Poverty and famine combined with frequent outbreaks of pandemics and incessant wars left Europe devastated and traumatised. This is quite evident in the art of the time, as seen in the development of the dance macabre (dance of death) genre in visual arts, music and literature. The reality of trauma and suffering also reflects in the writings of the 16th century reformers.

How did someone like Luther respond to the challenges of a changing and traumatised society? Not as a quasipolitician, but as a Christian and theologian (Brecht 1986:339). Luther was very much under the impression of the challenges of the time. The relation between spiritual and earthly matters became a major theme in Luther's work (Bornkamm 1979:314). This could be illustrated by two short examples.

In a letter to Melanchthon (dated 13 July 1521), Luther emphasised the importance of maintaining good order, without which the church will find it difficult to exist (WA Br. 2 Nr. 418:356-3610). With reference to Rom. 13 and 1 Pet. 2 , he argues that political authority comes from God and whoever resists authority is resisting the divine order of things (see Lohse 1995:167). 'Reformed' must be read in context of the radical Anabaptists who rejected all forms of earthly government, seeking to establish a perfect theocracy. The Anabaptist opposition to civil authorities led to immense trauma, bloodshed, public executions and lawlessness. Luther consistently opposed the actions of the radical reformers through his theological publications. He calls leaders who incite their followers to political violence and bloodshed 'false prophets who act violently under the pretence of Christian freedom', a clear reference to Thomas Müntzer, one of the leaders of the Radical Reformation (Bornkamm 1979:325; Dreyer 2018:3-4). In such a way, Luther became personally and theologically involved with some of the burning issues of his time.

In 1525, the Zwölf Artikel der schwäbischen Bauernschaft appeared (Zahrnt 1983:134). A popular revolt was brewing for some time under peasant farmers, which erupted in 1524 and spread across German-speaking territories in Central and Northern Europe. The leaders of the revolutionaries presented the 12 Articles to Luther, to which he responded with his well-known Ermahnung zum Frieden auf die zwölf Artikel der Baurnschaft in Schwabe (WA 18: 291-334). Luther explains to the protesting farmers that they are mistaken in their understanding of both the kingdom of God and of the kingdom of this world if they think they can use the gospel to justify political violence (Zahrnt 1983:135). Luther was of the opinion that violent protests will hamper the proclamation of the Word, it will lead to bloodshed and it will destroy the spiritual well-being of all involved. Luther was correct in his assessment of the situation. Almost 100000 peasant farmers perished during battle or by execution.

Luther's political views are sometimes criticised because it could silence the prophetic voice of the church, leaving all temporal matters in the hands of the 'Christian' government. It leads to a passive and obedient people, seeing themselves as Fürstenknecht (Zahrnt 1983:131). However, Luther's doctrine of two regiments is not limited to the Christian's relation to government but includes the everyday life of Christians in this world (Zahrnt 1983:132). A Christian must remain a citizen of God's kingdom and this world. For that reason, every Christian has a responsibility towards the kingdom of God and towards society. The Christian needs to be a brother and sister to everybody else. In his theology, Luther not only responded to important sociopolitical issues but also to the everyday existence of the common people.

Luther's responded to the traumatic events of his time in and through his theology. He did not hesitate to address difficult sociopolitical questions, which impacted the lives of the people. Maybe the time has come to develop a 'theology of trauma', which would be different from a 'theology of liberation' or 'theology of gender', although there might be many similarities.

\section{Calvin}

Calvin had a fundamental awareness of the relevance of Christian faith within a changing and traumatised society. Even as a young man, he writes extensively on sociopolitical issues. An early example of this is his 'Commentary on Seneca's De Clementia' (see Dreyer 2018), in which he argues for clemency, a humane (humanitas) treatment of people and respect for their dignity (dignitas). He not only reacted to sociopolitical issues but in some instances also initiated actions. According to Balserak (2013:160), one of the myths surrounding Calvin is the notion that he was all about order and peace. This is a very limited view of Calvin. It negates the fact that Calvin could be quite revolutionary in his ideas, but never a radical revolutionary activist Balserak (2013:171). He even supported individuals who held views, which were clearly seditious. He was of the opinion that magistrates not only had the right to resist tyranny but also had the duty to protect people against tyranny (CO 1:248). 
The 16th century was a period of terrifying change. The reformers had to respond intellectually and practically. Calvin's response to social change was quite extensive not only in terms of publications (intellectually) but also in practical ways in Geneva (Dreyer 2016). On a practical level, his involvement with the diaconate and hospital in Geneva is a clear indication of his social consciousness and concern for the welfare of people who were traumatised by wars, forced immigration and destruction of families (see Innes 1983).

Political violence, war and local conflict increased as the Reformation progressed. Calvin maintained correspondence with the leaders of the French reformation movement, which had strong political undertones leading to conflict with the French King. The conflict reached its zenith with the Bartholomew Day Massacre in Paris (1572). This sociopolitical awareness and involvement in often traumatised societies is still a feature of reformed theology and churches.

These few examples serve to demonstrate how reformers like Luther and Calvin responded to the existential crises, trauma and change of their time. It is part of the reformed deoxyribonucleic acid (DNA) to engage with sociopolitical issues, including the trauma people experience.

\section{Barth}

Karl Barth is well-known for his opposition to Hitler and National Socialism before World War II. After the War, he was an outspoken critic of the war in Vietnam and the Cold War, especially the nuclear armament programme. Barth was a public theologian par excellence, participating on a very regular basis in radio talks, television interviews and speaking to journalists of newspapers and magazines. His influence was such that he appeared on the front page of Time Magazine (20 April 1962). Barth had a magisterial ability to reflect on social issues and collective trauma from the perspective of Reformed theology. In fact, his rejection of liberal theology in his very first publication (Der Römerbrief) was partly the result of his disillusionment with liberal theologians who seemed unable to reflect critically on the issues of the day, including the unholy glorification of race and power (Dreyer 2017):

\footnotetext{
Der Römerbrief was Barth's first attempt to articulate the gospel in a new way in a context of war, growing secularism and modernism. The dramatic events before and after World War I are evident in Der Römerbrief. The existential crisis of the church and the loss of credibility of many theologians who supported the war, form the environment in which Barth worked on Der Römerbrief. Barth started his journey as theologian with misery and poverty all around him. Millions of people died and Europe was laid to ruin. Barth was convinced that the Bible had something to say about that. (p. 4)
}

It is also important to note that Barth responded to the trauma of his time in terms of ecclesiology. Barth understood the church as the work of the Holy Spirit, who unites people with, in and through Jesus Christ into one body. In this continual act of unification between Christ and His body, the church becomes visible and present in the world as God's people (Barth 1947:189). The church manifests in communities, living a holy life as God's people and ministering to wounded and traumatised people. The calling of the church is the proclamation of the gospel of Jesus Christ and kingdom of God, in complete freedom (from worldly ideology and powers) and obedience to God (Barth 1947:191). This is the healing ministry Reformed theology and churches render to a struggling and traumatised humanity. The church is the space where Christ is present and is experienced as present through the Holy Spirit. It is a holy space where people are healed and pray together as a community of faith (Barth 1967:130-131).

In the church, the body of Christ becomes visible. This has very particular implications, which Barth formulates as follows (my translation): Faith is life. Life means labour. Labour means being here and not everywhere. Confessing the church means saying 'yes' to a real life and presence in the church (Barth 1967:135). Being church means saying 'yes' to life, to the church and to the world which belongs to God. Being a Christian is never just private business (Busch 1998:246). It means being present in the world.

\section{An ecumenical response}

In the decades after World War II, many theologians, churches and ecumenical bodies (like the World Council of Churches) became involved in the growing conflict in South Africa. As the armed struggle and civil protests escalated during the 1960s, South Africans were subjected to all forms of violence. Retaliation and counter-retaliation became the order of the day.

Many influential documents (e.g. the Kairos Document, Belhar Confession and Rustenburg Declaration) appeared that articulated a theological response to the growing conflict and trauma in South Africa. One example of such a theological response to the traumatic events in South Africa is to be found in the documents of the Cottesloe Consultation of the World Council of Churches. After the Sharpeville massacre (21 March 1960), the debate on racial relations and the political future of South Africa intensified tenfold. In response to these traumatic events, the World Council of Churches and South African member churches agreed that a consultation of churches would be of extreme importance. The consultation took place in December 1960 in Cottesloe, Johannesburg.

The Cottesloe Consultation urged the churches in South Africa to condemn Apartheid as contrary to Christian principles and unworkable in practice. The Afrikaans churches found this very difficult, especially against the backdrop of rising Afrikaner nationalism. The purpose of the Cottesloe Conference was to reject all forms of social injustice. The minutes of the Cottesloe Consultation reveals a deep compassion for the welfare of the people of South Africa, 
traumatised by conflict and violence (Minutes Cottesloe Conference 1960):

The Church of Jesus Christ, by its nature and calling, is deeply concerned with the welfare of all people, both as individuals and as members of social groups. It is called to minister to human need in whatever circumstances and forms it appears, and to insist that all be done with justice. In its social witness the Church must take cognisance of all attitudes, forces, policies and laws which affect the life of a people; but the Church must proclaim that the final criterion of all social and political action is the principles of Scripture regarding the realisation of all men of a life worthy of their God-given vocation. (pp. 73-74)

The Cottesloe Conference had little effect on the implementation of Apartheid. Churches continued to maintain segregated structures and the political violence escalated. It raised the question whether the prophetic voice of the (white) Reformed churches was silenced by the state or by fear of losing their members. Many church leaders were of the conviction that the church should not be involved in sociopolitical issues. On the other hand, Reformed churches and theologians from disadvantaged communities, who experienced the effects of Apartheid first-hand, were very much involved in the struggle against Apartheid not only politically but also in supporting people in their hour of need.

Despite the negative reaction to the Cottesloe Consultation by Afrikaans churches, some of the theologians and clergy who had become disillusioned by the lack of response to the looming crisis and perceived servitude of churches and theologians to political agendas and ideology, responded as theologians. They started a movement that became known as the Ekumeniese Studiekring. It eventually evolved into the Christian Institute (CI), of which Dr. Beyers Naudé was the director and Prof. Albert Geyser was the first chairman. Eleven members of the Studiekring published a booklet with the title Vertraagde Aksie, which was translated as Delayed Action (eds. Geyser \& Keet 1960). In this publication, the authors voiced their criticism of government and church Apartheid. The 11 authors who contributed to the publication were A.S. Geyser, A. Van Selms, M.J. Redelinghuys and J. Stutterheim (clergy from the Ned. Hervormde Kerk); B.B. Keet, B.J. Marais, G.C. Oosthuizen, J.A. Van Wyk and G.J. Swart (clergy from the Dutch Reformed Church) and H. Du Plessis and C. Hattingh (clergy from the Gereformeerde Kerke) (see Dreyer 2016:1-3).

\section{Concluding remarks: A contemporary response to collective trauma}

Trauma (either personal or collective) never disappears, but if it is acknowledged and addressed some peace of mind could be restored. An abnormal society could transform into one where peaceful co-existence is possible. How does (Reformed) theology respond to the collective trauma evidently present in the South African society?
Firstly, by accepting that the rainbow above South Africa is not pointing to a pot of gold, but rather to an unholy brew of pent-up anger, frustration, fear and trauma. There is nobody in South Africa, irrespective of race, age or gender who had not been affected by the collective trauma, which permeates society. It is relatively easy to look back into history and criticise, it is much more difficult to be critical of the current situation. The lack of prophetic witness in the past is only equalled by the deafening silence of theologians and churches on state corruption, incompetency in local governments, mismanagement of the economy, the collapse of medical facilities, bad management of the Covid-19 epidemic, lack of proper police work and an ineffective judicial system. This is doing nothing to address inequality, poverty and collective trauma.

Secondly, by accepting the responsibility to speak about individual and collective trauma. As we have seen with theologians like Luther, Calvin and Barth, and we could have added Augustine and Chrysostom from the early church and South Africans such as Buthelezi, De Gruchy, Boesak, Tutu, Naudé, Geyser and many others, a fundamental responsibility rests on theologians and theology to reflect on and engage with the challenges facing society. The Bible actually has something to say about the human condition and the suffering of people. If we believe that Christ is the epitome of human suffering and that he took our suffering upon Himself, the gospel is relevant. How does Reformed theology engage the challenges facing South Africa, and more specifically, collective trauma?

Thirdly, personal and collective trauma require different responses. The first requires a pastoral approach, which would presuppose trauma, especially in assisting people with feelings of anger, guilt and shame. This would require that theological education and the training of ministers should include modules on trauma and how to care for people suffering from individual and collective trauma.

Fourthly, it is the calling of theologians and churches not only to speak about the presence of God in the midst of trauma but also making God present in the way that theology and church is present in the world. If the church is the body of the suffering and resurrected Christ, church and theology should engage with suffering, not in despair and without hope, but with faith in the resurrection and a new life in Christ. We should speak about God's love, but not love without justice, which is mere sentimentality. We should speak about justice, but not without love (see Van Aarde 2016).

Finally, by being brave, Barth once wrote that the church always 'becomes courageous thirty years too late' (Barth 1928:102). It reminds of the famous reformer of Zürich, Huldrych Zwingli, who had a sign put up in the consistory of his church: Tut um Gott's Willen etwas Tapferes .... [For God's sake, just do something brave]. In a time of trauma, political tension, pandemics, rampant murder and violence, 
churches and theologians need to be brave, the bravery of being church and speaking out against the evils besetting our beloved country. Since Alan Paton published Cry, the Beloved Country (1948), the crying hasn't stopped. Maybe, if more theologians would listen to the crying of people instead of keeping themselves busy with personal academic agendas which seem to have very little to do with the world we live in, things could change for the better (Paton 1948).

Cry, the beloved country, for the unborn child that is the inheritor of our fear. Let him not love the earth too deeply. Let him not laugh too gladly when the water runs through his fingers, nor stand too silent when the setting sun makes red the veld with fire. Let him not be too moved when the birds of his land are singing, nor give too much of his heart to a mountain or valley. For fear will rob him of all if he gives too much ... (p. vi)

\section{Acknowledgements Competing interests}

The author declares that he has no financial or personal relationships that may have inappropriately influenced him in writing this article.

\section{Author's contribution}

W.A.D. is the sole author of this research article.

\section{Ethical considerations}

This article followed all ethical standards for research without direct contact with human or animal subjects.

\section{Funding information}

This research received no specific grant from any funding agency, in the public, commercial, or non-profit sectors.

\section{Data availability}

Data sharing is not applicable to this article as no new data were created or analysed in this study.

\section{Disclaimer}

The views and opinions expressed in this article are those of the author and do not necessarily reflect the official policy or position of any affiliated agency.

\section{References}

Afriforum Research Institute, 2019, 'Farm attacks and farm murders in South Africa: Analysis of recorded incidents 2019', viewed 01 July 2020, from https://www. afriforum.co.za/wp-content/uploads/2020/07/Farm-attacks-and-farm-murdersin-South-Africa-Analysis-of-recorded-incidents-2019.pdf.

Alexander, J.C., 2012, Trauma: A social theory, Polity, Cambridge.

Balserak, J., 2013, 'Examining the myth of calvin as a lover of order', in P. Opitz (ed.), The myth of the reformation, pp. 160-175, Vandenhoeck \& Ruprecht, Göttingen.

Barth, K., 1928, Die Theologie und die Kirche, Chr. Kaizer Verlag, München.

Barth, K., 1947, Dogmatik im Grundriss im Anschluss an das apostolische Glaubensbekenntnis, W. Kohlhammer Verlag, Stuttgart.

Barth, K., 1967, Das Glaubensbekenntnis der Kirche, transl. H. Goes, EVZ-Verlag, Zürich.

Bornkamm, H., 1979, Martin Lutherin der mitte seines lebens, Vandenhoeck \& Ruprecht, Göttingen.

Brecht, M., 1986, Martin Luther, Ordnung und Abgrenzung der reformation, 1521-1532, Band 2, Calwer Verlag, Stuttgart.

Busch, E., 1998, Die Grosse Leidenschaft. Einführung in die Theologie Karl Barths, Chr. Kaiser Gütersloher Verlaghaus, Gütersloh.

Business Tech, 2019, '4 Scary facts about emigration in South Africa', viewed 30 September 2019, from https://businesstech.co.za/news/lifestyle/337531/4scary-facts-about-emigration-in-south-africa/.

Claasen, L., 2017, Plaasaanvalle en plaasmoorde in Suid-Afrika, Afriforum Navorsingsinstituut, Centurion.

Dreyer, W.A., 2016, 'Heretic or rebel? The heresy trial of Albert Geyser', HTS Teologiese Studies/Theological Studies 72(4), a3745. http://doi.org/10.4102/hts.v72i4.3745

Dreyer, W.A., 2017, 'Karl Barth's Römerbrief: A turning point in protestant theology', Studia Historiae Ecclesiasticae 43(3), 1-15. https://doi.org/10.17159/2412-4265/3183

Dreyer, W.A., 2018, 'John Calvin as "public theologian" in view of his "Commentary on Seneca's de Clementia"', HTS Teologiese Studies/Theological Studies 74(4), a4928. https://doi.org/10.4102/hts.v74i4.4928

Geyser, A.S. \& Keet, B.J. (eds.), 1960, Vertraagde aksie: ' $n$ Ekumeniese getuienis vanuit die Afrikaanssprekende kerk, Geyser \& Keet, Pretoria.

Hopfl, H. (ed.), 1991, Luther and Calvin on secular authority, Cambridge University Press, Cambridge.

Innes, W.C., 1983, Social concern in Calvin's Geneva, Pickwick Publications, Allison Park, PA.

Lohse, B., 1995, Luthers Theologie in ihrer historischen Entwicklung und in ihrem systematischen Zusammenhang, Vandenhoeck \& Ruprecht, Göttingen.

Mannion, G., 2009, 'A brief genealogy of public theology, or doing theology when it seems nobody is listening', Annali di Studi Religiosi 10, 121-154.

Nelson Mandela Centre of Memory, n.d., Chapter 4: The liberation movements from 1960 to 1990, viewed 28 October 2019, from https://omalley.nelsonmandela.org/ omalley/index.php/site/q/03lv02167/04lv02264/05/v02335/06lv02357/ 07lv02372/08lv02376.html.

Paton, A., 1948, Cry, the beloved country, Scribner, New York, NY.

South African Police Service, n.d., Crime situation in RSA: Twelve months 01 April 2017 to 31 March 2018, viewed 15 October 2019, from https://www.gov.za/sites/ default/files/gcis_document/201809/crime-stats201718.pdf.

Statistics South Africa, 2020, Governance, Public Safety and Justice Survey, Statistical Release P0341, Department of Statistics South Africa, Pretoria, viewed 01 February 2020, from http://www.statssa.gov.za/?page id=1854\&PPN=P0341\&SCH=7678.

Taylor, R., 2002, Justice denied: Political violence in KwaZulu-Natal after 1994, Vol. 6, Violence and transition series, Centre for the Study of Violence and Reconciliation, Johannesburg.

The Center for the Treatment of Anxiety and Mood Disorder, n.d., What is trauma?, viewed 25 October 2019, from https://centerforanxietydisorders.com/what-istrauma/.

Van Aarde, T., 2016, 'Black theology in South Africa - A theology of human dignity and black identity', HTS Teologiese Studies/Theological Studies 72(1), a3176. http:// doi.org/10.4102/hts.v72i1.317

WA, D., Martin Luthers Werke, Kritische Gesammtausgabe, Band 1-60 (1883-1983), Hermann Böhlaus, Weimar.

Zahrnt, H., 1983, Martin Luther in seiner zeit - für unsere Zeit, Süddeutscher Verlag, München. 